УДК $323.11+39$

DOI $10.21661 / \mathrm{r}-467223$

\title{
Т.И. Нараева
}

\section{ЭТНИЧЕСКИЕ ГРУППЫ У КАЛМЫКОВ:}

МАТЕРИАЛЫ О ГРУППЕ ЗЁД (ЗӨД)

Аннотация: ойраты, пришедшие в степи Нижнего Поволжья, имели разнообразный этнический состав, включавший ойратские, тюркские и монгольские по происхождению группыл. Многие тюркские этнические группы Саяно-Алтая были включены в состав ойратов в период Джунгарского ханства. Анализ материалов по этнической группе зёт в составе субэтноса дербетов Калмылкии позволяет сделать выводы о тюркском происхождении группь, что также сохраняется в предании о родоначальнике рода. Сравнительный материал по тюркским народам подтверждает наши выводьл.

Ключевые слова: тюрко-монгольские народы, калмыки, этнический состав, иноэтничный компонент, тувинцьь.

\section{T.I. Sharaeva \\ THE KALMYKS' ETHNIC GROUPS: INFORMATION ON ZED (ЗӨД) GROUPS}

Abstract: oirats who came to the steppes of the Lower Volga region had a diverse ethnic composition, including Oirat, Turkic and Mongolian by origin groups. Many Turkic ethnic groups of the Sayano-Altai were included in the Oirats in the period of the Dzungarian Khanate. The analysis of materials on the ethnic group in the subethnos of the Kalmyk derbets allows one to draw conclusions about the Turkic origin of the group, which is also preserved in the legend of the ancestor of the genus. Comparative material on the Turkic peoples confirms our conclusions.

Keywords: Turkic-Mongolian peoples, Kalmyks, ethnic composition, ino-ethnic component, Tuvinians. 
Калмыки - этнос, сложившийся из различных этнополитических объединений ойратов (дербетов, торгутов, хошутов), пришедших в степи Нижнего Поволжья в XVII веке из Центральной Азии. Каждое из этих объединений имело сложный этнический состав, и как отмечали исследователи в них входили остатки древних тюрко-монгольских родоплеменных групп как, например, хойты, меркиты, урянхусы, батуты, цоросы, кереиты, чоносы, абганеры и др [5, с. 63]. Как отмечал Г.О. Авляев, в описании этнического состава калмыков в начале $\mathrm{XX}$ века, «калмыки как этнос прошли сложный и весьма длительный исторический путь, в процессе которого имели разнообразные этнические, историкокультурные и другие контакты с народами Центральной Азии, Южной Сибири, Средней Азии и Поволжья» [2, с. 5]. В настоящее время вопросы этнического состава калмыков все еще остаются малоисследованными.

В составе субэтнической группы дербетов есть этническая группа зёт (зөд). Ее представители большей часть проживают в Малодербетовском районе Республики Калмыкия, есть род зёт (зөд) в субэтнической группе бузавов, проживающие в Зимовниковском и Сальском районе Ростовской области. Считается, что они пришли на Волгу в XVII веке в составе бурульских родов дербетов, которые имели «...в себе некогда пять главных родов: Туктунов, Бурулов, Зюнев, Шабинеров и Абганеров, из числа их первые четыре прибыли из Зюнгарии, а последний образовался уже в России, в начале прошедшего столетия» [4, с. 321]. На протяжении XVII-XVIII вв. бурульь являлись одним из наиболее крупных таксонов Дербетовского улуса*. Небольшая часть зётов также была в составе Зюновских родов этого же улуса. После ухода значительной части калмыков с территории России в 1771 году на территорию бывшей Джунгарии, изменились этнический состав оставшихся улусов, их численность и территории кочевий. К тому же именно в Дербетовском улусе в XVIII - XIX веках происходило постоянное дробление аймаков** внутри улуса. По данным К. Костенкова в середине XIX века среди бурулов числились зёты зайсанга Аршиева 119 кибитки, в составе зюнов - 51 кибитка зет-кебютов зайсанга Арабданова [4, с. 337]. Зет- 
кевюды в составе зюновских родов были приходом Сампил Норбо хурула по отчету главы дербетовских хурулов южной части улуса [10, с. 127].

В начале XX века после разделения Малодербетовского улуса на две части (собственно Малодербетовский улус и Манычский) рода тевктнеры (83 киб.), шаряды (45 киб.) и зёды (192 киб.) [4, с. 337] оказались в списках родов Малодербетовского улуса, причем численность их значительно возрастает, а территория кочевий смещается. Необходимо также отметить, что в списках уже Манычского улуса зет-кебюты (ики-зет-кебюты) указаны как ики-кебюты в количестве 284 кибитки, или семей. Они кочевали по урочищам Манцын-Улан-Зуха, Манцын-Шара-Булук. Необходимо отметить, что кебюты (кебюты, кевюны, кевюды) считались у калмыков социальной группой, а термин «кебюн» (калм. көвүн - мальчик, юноша) обозначал прислугу, домашнюю челядь. Какая-то часть зет-кебютов попала во второй половине XIX века на Дон, где разделились на зёт (зөд) и маанин зёт (маанин зөд). Последние были названы так из-за принадлежности к хурулу и выполнению там обязательных работ (калм. маань - молитва; текст молитвы, напечатанный на ткани, бумаге - Т.Ш.) [3, с. 9, 10]. Рода зёт, бывшие в Манычском улусе, в настоящее время составляют этническую группу кевюды, большинство их проживает в поселке с одноименным названием в Ики-Бурульском районе РК.

Небольшое количество зётов входило в состав этнической группы Дунду хурульские шабинеры (проживают ныне в Малодербетовском районе РК). Согласно существующей легенде, они были переданы в количестве 40 кибиток (семей) их нойоном в дар буддийскому монастырю, согласно существовавшей в то время традиции. Потомки этих зётов, составляя одно из родовых объединений, проживают в поселке Унгун Тёрячи Малодербетовского района РК совместно с родами аадждуд и джеджетены [11, с. 160-162].

В 20-х годах XX века аймак, в котором проживали зёты в Малодербетовском улусе вошел в состав Царицынской губернии (теперь этот район входит в состав Волгоградской области). Рода зёт (зөд), капкихины (капкихн), тергтнер абганеры (тергтн авһнр), шаряды (маряд) и тевктнеры (тевктнр) были 
объединены под общим названием «Ар тавн һол» («Пять северных рек»). Они проживали в селах Червленное (тергтнер абганеры), Красноселец (шаряды), Березов (капкихины), Привольный (тевкнеры), Северный (зёт). Единство родов отображалось в виде крестообразно соединенных пяти колец (три по вертикали, два по бокам) на тамге (тавро) как родовом знаке. Зёты кочевали у рек Донская Царица и Бургуста, а также и по балкам Песчаной, Худжирта, Крутой (Надбитов 2011: 32). В их составе были следующие арваны***: «зэд, абганер, шаряд, харнуд, бурул, номчуд» [12, с. 108]. Вероятно, большее количество арвн отображено в источнике из-за того, что несколько из них входили в один род, как это было принято у калмыков.

Именно о родах «Ар тавн һол» упоминал в своем отчете о поездке к Астраханским калмыкам в 1909 году Номто Очиров, направленный Восточной секцией Русского комитета для изучения Средней и Восточной Азии, для сбора образцов народного фольклора, составления описания этнического состава и быта калмыков. Как отметил исследователь: «...состоит из 4-х десятков (арвн): абһнр арвн, номчд арвн, харнд арвн и зөд арвн (от последнего происходит и название всего рода). По рассказам одного стрика, был когда-то татарин «Жөд», который какими-то судьбами попал к калмыкам и явился родоначальником «зөд арвн». Согласно его данным абганеры (тергтнр абганеры) были выходцами из рода с одноименным названием в Малодербетовском улусе, род «номчуд» назван так, потому что «из его среды выходили образованные духовные лица», образовавшие позднее хурул, а появление названия четвертого рода ему не удалось выяснить потому, что «...выяснить происхождение названия родов и десятков очень трудно; здесь нашла себе широкое применение народная этимология» [7, с. 41]. Согласно данным этого предания и зафиксированных нами у информантов (тексты предания почти сходны) у зётов было тюркское происхождение. В современных вариантах легенды имя предка указывается как Изөд или Зөд.

По мнению Г.О. Авляева термин зёт у калмыков представляет собой «калмыцкий вариант произношения тувинского, а точнее самодийского этнонима чom, чоот, чоогду (йоm, дьem)» [1, с. 363]. Как предположил исследователь, зеты 
попали в состав ойратов, этнических предков калмыков, будучи еще в составе «лесных племен» Алтая, бывшими данниками Джунгарского ханства. После гибели ханства какая-то часть предков зетов осталась на территории Монголии, другая часть с дербетами попала в Нижнее Поволжье. Возможно, подтверждением этому может служить то, что представители этнической группы зёт проживали и проживают в Калмыкии среди представителей субэтнической группы дербетов.

С точки зрения монгольского этнолога А. Очира, зөөд относятся к потомкам самодийских родов, которые издревле расселялись в Южной Сибири и, будучи ассимилированы ойратами (дербетами и баятами) и хубсугульскими дархатами, омонголились. «При этом зөөд появились среди дербетов, баятов и калмыков еще до того, как дербеты переселились на волжские земли» [6, с. 95], что и определило наличие одноименных групп среди дербетов Монголии и дербетов Калмыкии.

Как отмечает А. Очир зафиксированые среди хубсугульских дархатов названия родов хар зоот, цагаан зоот и иар зоот, ученый определенно считает одним из вариантов этнонима зөөд и связывает с названиями чжот, чогду, джеты, джокду, чеда, джода и чота, отмечая, что они есть среди алтайцев и шорцев. Названия тувинских и хакасских родов чооду, ак чооду и кара чооду А. Очир также считает вариантом терминов зөөд и зоот [6, с. 94, 95]. При рассмотрении этнического состава алтайцев Л.П. Потапов указывал, что алтайский сеок Чооты, или Йоты, образовался среди кумандинцев и тубаларов из-за переселения телеутских родов. Об этом упоминается в предании о переходе двух братьев, родоначальников этих родов, из Аккыштымской волости Кузнецкого уезда на Бию [8, с. 60]. Предваряя описание родов чооду у тувинцев, Л.П. Потапов отмечал,

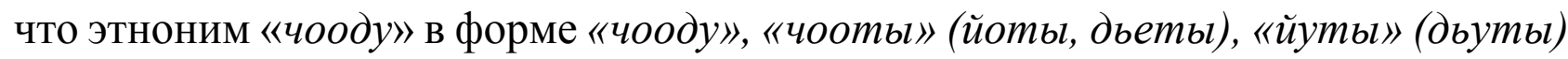
известен кроме тувинцев у тофаларов, телеутов - ак-киштымов, кумандинцев, тубаларов, хакасов (койбалы). По его данным, в Туве чооду проживали в нескольких местах и находились в трех хошунах: Оюннарском (чооду составляли особый сумон), Тоджинском (ак-чооду и кара-чооду) и Да-вана. Южные чооду 
(нарынская группа), которых соседние моголы называли харь чоод, т.е. черные чооду (тув. Кара-чооду) были компактной группой в Эрзинском районе. Их появление в этом районе предание относит к первой половине XIII века и связывает с именем Бату, внука Чингис-хана. Согласно преданию, чооду появились в Туве как военнопленные. Прародитель эрзинских чооду был куплен Бааты-ханом (Бату-ханом). Затем он вошел к нему в доверие и был им поставлен для охраны границы в Эрзине. У этого чооду было семь сыновей и семь дочерей, от которых и размножились чооду [9, с. 62].

Таким образом, анализ материалов по этнической группе зёт в составе субэтноса дербетов-калмыков позволяет сделать выводы о нахождении ее в составе еще с ойратского периода. Предположение об общем происхождении калмыцких родов зётов с тюркскими племенами Саяно-Алтая, подтверждается в рассмотренных нами материалах. Тюркское происхождение представителей этнической группы зёт сохраняется в предании о родоначальнике рода.

Примечания

*Улус - крупная административно-политическая единица (численность примерно от 4 тысяч и до 15 тысяч и более кибиток, или семей).

**Аймак - средняя административная единица, численностью от 300 и до 600-800 и более кибиток.

***Арвн - родовая группа.

«Сочиикультурные, этногенетические и этноантропологические исследования родовых групп народов Центральной Азии (на примере Республики Тыва, Республика Алтай, Республики Калмылкя, Монголии и Синьцзянь-Уйгурского Автономного округа Китая)» № 16-21-03002/17-ОГОН.

\section{Список литературы}

1. Авляев Г.О. О тюркских этнических компонентах в этническом составе приволжских калмыков конца XIX в [Текст] / Г.О. Авляев // Проблемы современной тюркологии: Материалы II всесоюзной тюркологической конференции (2729 сентября 1976 г.). - Алма-Ата: Наука КазССР, 1980. - С. 361-364. 
2. Авляев Г.О. Происхождение калмыцкого народа [Текст] / Г.О. Авляев. 2-е изд., перераб. и исправл. - Элиста: Калм.кн. изд-во, 2002. - 325 с.

3. Алексеева П.Э. Об этническом составе донских калмыков [Текст] / П.Э. Алексеева, А.Э. Борманджинов. - Элиста: АПП «Джангар», 1999. - 41 с.

4. Митиров А.Г. Ойраты - калмыки: века и поколения [Текст] / А.Г. Митиров. - Элиста: Калм.кн. изд-во, 1998. - 384 с.

5. Очерки истории Калмыцкой АССР. Дооктябрьский период [Текст] / Под ред. Н.В. Устюгова и др. - М.: Наука, 1967. - 480 с.

6. Очир А. Монгольские этнонимы: вопросы происхождения и этнического состава монгольских народов [Текст] / А. Очир. - Элиста: КИГИ РАН, 2016. $304 \mathrm{c}$.

7. Очиров Н. Избранные труды Номто Очирова [Текст] / Н.Очиров. (Сер. «Номин зөөр» («Научное наследие»). - Элиста: АПП «Джангар», 2002. - 152 с.

8. Потапов Л.П. Этнический состав и происхождение алтайцев [Текст] / Л.П. Потапов. - Л.: Наука, Ленинградское отделение, 1969. - 196 с.

9. Потапов Л.П. Очерки народного быта тувинцев [Текст] / Л.П. Потапов. М.: Наука, Глав. ред. вост. лит. - 1969 (б). - 402 с.

10. Шараева Т.И. К вопросу об этническом составе аймака бурул и одноименной группы родов субэтнической группы дербетов-калмыков [Текст] / Т.И. Шараева // Проблемы этнической истории и культуры тюрко-монгольских народов: сборник научных трудов / Рос. акад. наук, Калм. ин-т гуманитар. исслед. РАН. - Элиста: КИГИ РАН, 2009. - Вып. 1. - С. 124-130.

11. Шараева Т.И. Этническая группа Дунд хурла шевнр: фольклорные источники по истории возникновения групп (по данным полевых материалов) [Текст] / Т.И. Шараева // Проблемы этнической истории и культуры тюрко-монгольских народов: сборник научных трудов / Рос. акад. наук, Калм. ин-т гуманитар. исслед. РАН. - Элиста: КИГИ РАН 2008. - Вып. 2. - С. 158-163.

12. Эрдниев У.Э. Материалы по калмыцкой этнонимии [Текст] / У.Э. Эрдниев // Вестник института. (Сер. этнография). - Элиста: КНИИЯЛИ, 1974. Вып. 10. - С. 99-115. 


\section{References}

1. Avlyaev G.O. Problemi sovremennoi tyurkologii. Abstracts of Papers. September 27-29, 1976. - Alma-Ata, Nauka KazSSR, 1980. P. 361-364.

2. Avlyaev G.O. Proishojdenie kalmickogo naroda. Elista, Kalm. kn. Izd, 2002. $325 \mathrm{p}$.

3. Alekseeva P.E._ Bormandjinov A.E. Ob etnicheskom sostave donskih kalmikov. Elista, APP «Djangar», 1999. 41 p.

4. Mitirov A.G. Oirati - kalmiki_veka i pokoleniya. Elista, Kalm. kn. Izd-vo, 1998. $384 \mathrm{p}$.

5. Ocherki istorii Kalmickoi ASSR. Dooktyabrskii period. Moscow, 1967. 480 p.

6. Ochir A. Mongolskie etnonimi_voprosi proishojdeniya i etnicheskogo sostava mongolskih narodov. Elista, KIGI RAN, 2016. 304 p.

7. Ochirov N. Izbrannie trudi Nomto Ochirova. Elista, APP «Djangar», 2002. Ser. «Nomin z??r», «Nauchnoe nasledie». 152 p.

8. Potapov L.P. Etnicheskii sostav i proishojdenie altaicev. Leningrad, Nauka, Leningradskoe otdelenie, 1969. - $196 \mathrm{p}$.

9. Potapov L.P. Ocherki narodnogo bita tuvincev. Moscow, 1969. - 402 p.

10. Sharaeva T.I. K Voprosu ob etnicheskom sostave aimaka burul i odnoimennoi gruppi rodov subetnicheskoi gruppi derbetov_kalmikov. Article in Problemi etnicheskoi istorii i kulturi tyurko_mongolskih narodov. Elista, 2009. pp. 124-130

11. Sharaeva T.I. Etnicheskaya gruppa Dund hurla shevnr (folklornie istochniki po istorii vozniknoveniya grupp po dannim polevih materialov). Article in Problemi etnicheskoi istorii i kulturi tyurko_mongolskih narodov. Elista, 2008. pp. 158-163

12. Erdniev U.E. Materiali po kalmickoi etnonimii. Vestnik instituta. Elista, 1974. Ussue 10. Ser. ethnography. Pp. 99-115.

Шараева Татьяна Исаевна -

канд. ист. наук, старший научный сотрудник отдела истории, этнологии и археологии ФГБУН «Калмыцкий научный центр РАН», Россия, Элиста. 
Sharaeva Tatiana Isaevna - PhD in History, senior scientist of History, Ethnology and Archeology Department at Kalmyk Scientific Center of the RAS, Russia, Elista. 